Borut Peterlin · Mojca Globočnik Petrovič

Jana Makuc $\cdot$ Marko Hawlina $\cdot$ Daniel Petrovič

\title{
A hemochromatosis-causing mutation C282Y is a risk factor for proliferative diabetic retinopathy in Caucasians with type 2 diabetes
}

Received: 7 August 2003/ Accepted: 29 September 2003/Published online: 15 November 2003

(C) The Japan Society of Human Genetics and Springer-Verlag 2003

\begin{abstract}
Iron metabolism might be involved in the pathogenesis of type 2 diabetes and in the pathogenesis of diabetic retinopathy. $\mathrm{C} 282 \mathrm{Y}$ and $\mathrm{H} 63 \mathrm{D}$ mutations in the hemochromatosis (HFE) gene are associated with increased serum iron levels and consequently with hereditary hemochromatosis. In the present study, we searched for a relationship between C282Y and H63D gene mutations and the development of proliferative diabetic retinopathy in Caucasians with type 2 diabetes. For this purpose, 90 subjects with type 2 diabetes with proliferative diabetic retinopathy (PDR) were compared to 133 diabetic subjects without PDR. There was a significantly higher frequency of the C282Y heterozygotes in patients with PDR compared to subjects without it $(\mathrm{OR}=3.0,95 \% \quad \mathrm{CI}=1.2-8.0$; $p=0.02$ ), whereas no association was demonstrated between PDR and H63D genotypes $(\mathrm{OR}=1.1,95 \%$ $\mathrm{CI}=0.6-2.2 ; \quad p=0.7)$. Logistic regression analysis revealed that the $\mathrm{C} 282 \mathrm{Y}$ mutation was a significant independent risk factor for the development of PDR $(\mathrm{OR}=6.1,95 \% \mathrm{CI}=1.2-30.5 ; p=0.027)$. These data suggest that heterozygosity for $\mathrm{C} 282 \mathrm{Y}$ might be a novel risk factor for PDR in Caucasians with type 2 diabetes.
\end{abstract}

B. Peterlin · J. Makuc

Division of Medical Genetics,

Department of Obstetrics and Gynecology,

University Medical Centre,

Ljubljana, Slovenia

M. Globočnik Petrovič · M. Hawlina Eye Clinic, University Medical Centre, Ljubljana, Slovenia

D. Petrovič $(\bowtie)$

Institute of Histology and Embryology,

Medical Faculty, University of Ljubljana,

Korytkova 2, 1105 Ljubljana, Slovenia

E-mail: daniel.petrovic@mf.uni-lj.si

Tel.: + 386-1-5437367

Fax: + 386-1-5437361
Keywords Hereditary hemochromatosis - C282Y mutation Proliferative diabetic retinopathy $\cdot$ Type 2 diabetes

\section{Introduction}

Diabetic retinopathy remains a leading cause of loss of vision in Europe and North America in working population. Despite improvements in metabolic control, proliferative diabetic retinopathy (PDR) continues to occur and affects approximately 10-20\% of subjects with type 2 diabetes. PDR represents a serious long-term diabetic complication with a substantial impact on the quality of life of diabetic patients (Klein et al. 1984).

Although several risk factors for progression of diabetic retinopathy to PDR have been identified (Porta et al. 2001, Keen et al. 2001), the underlying pathogenesis is still not known. PDR is characterized by active angiogenesis and the formation of fibrovascular tissue at the vitreoretinal interface. This process requires a local production of cell-derived angiogenic factors and synthesis of extracellular matrix components necessary for the anchorage of migrating endothelium.

The association between diabetic retinopathy and idiopathic hemochromatosis was reported in 1978 (Walsh and Malins 1978). Hereditary hemochromatosis is a late-onset, autosomal recessive disorder leading to a chronic iron overload syndrome. Hereditary hemochromatosis is the most common single gene disorder in northern Europeans that occurs with a frequency of approximately $0.5 \%$. In 1996, HFE, a gene for hereditary hemochromatosis, was cloned; the HFE gene is normally expressed in crypt enterocytes of the duodenum (Parkkila et al., 1997). Two of the 37 allelic variants of the HFE gene described to date (C282Y and H63D) are significantly correlated with hereditary hemochromatosis (Hanson et al. 2001). In the hereditary hemochromatosis, there is a primary defect in the HFE gene leading to increased intestinal absorption of dietary iron and net iron accumulation (Hanson et al. 2001). 
Iron metabolism has been recently associated with angiogenesis and extracellular matrix remodeling and fibrosis (Gardi et al. 2002, Parkes et al. 2000, Simonart et al. 2001). Moreover, emerging scientific evidence has disclosed bidirectional influences between iron metabolism and type 2 diabetes (Fernandez-Real et al. 2002). We therefore hypothesized that C282Y and H63D mutations could be associated with an increased risk of PDR progression via increased iron concentrations.

To test this hypothesis, we typed for $\mathrm{C} 282 \mathrm{Y}$ and H63D gene mutations a group of 223 patients with type 2 diabetes divided in two groups according to the presence or absence of PDR.

\section{Patients and methods}

In this cross-sectional, case-control study, 223 unrelated Caucasian subjects of Slovenian origin with type 2 diabetes with a defined ophthalmologic status were enrolled. For the diagnosis of diabetes mellitus, the standard WHO (1985) criteria were used. Subjects were recruited from the Eye Clinic and from the Diabetic Outpatient Clinic of the University Medical Centre Ljubljana. Staging of diabetic retinopathy was performed by a senior ophthalmologist (MP) after pupil dilatation (tropicamide and phenylephrine $2.5 \%$ ) using direct ophthalmoscopy and was electronically documented with a $50^{\circ}$-angle fundus camera (Topcon-TRC 40-IX; Tokyo, Japan). The study group consisted of 90 patients with PDR (new vessel formation or fibrous proliferation). The control group consisted of 133 subjects without PDR: 80 subjects with type 2 diabetes of more than 10 years' duration having no clinical signs of diabetic retinopathy, and 53 subjects with non-PDR (microaneurysms, retinal hemorrhages, hard exudates). To avoid the confounding effect of impaired kidney function, the patients with overt nephropathy were not enrolled. After informed consent was obtained, a detailed interview was made.

Arterial hypertension was defined as systolic blood pressure higher than $140 \mathrm{mmHg}$, diastolic blood pressure higher than $90 \mathrm{~mm} \mathrm{Hg}$, or both, at repeated measurements, or current use of antihypertensive agents for the confirmed diagnosis of arterial hypertension. Total cholesterol, low-density lipoproteins (LDL), high-density lipoproteins (HDL), and triglycerides were determined using standard biochemical methods. Patient and control subject characteristics are listed in Table 1; the groups were matched for most clinical parameters except for age and insulin treatment. The study was approved by the National Medical Ethics Committee.

Analysis of HFE gene mutation was performed using standard PCR with the primers described by Feder et al. (1996). After amplification, aliquots of the PCR products were digested with RsaI (C282Y) and MboI (H63D) restriction enzymes. The resulting fragments were run on a 3\% Nusieve 3:1 agarose gel and observed under UV illumination after ethidium bromide staining. Genotyping was done by two researchers (DP, BP) who were blinded to patients' retinopathy status. Differences in mean values were assessed by unpaired Student's $t$ test and presented as means \pm SD. Chi-square test was used to compare discrete variables. Logistic regression analysis was performed to assess the independent role of C282 mutation and other variables, including age, the age at onset of diabetes, gender, $\mathrm{HbA}_{\mathrm{lc}}$, systolic and diastolic blood pressure, and insulin therapy (categorical variable: insulin therapy or no therapy). Statistical significance was set at $p<0.05$. Statistical analysis was performed using the SPSS program for Windows version 11 (SPSS Inc. Il, USA).

\section{Results}

Clinical characteristics of the two groups are summarized in Table 1. Frequency of the genotypes of the
Table 1 Clinical characteristics of type 2 diabetes patients. PDR proliferative diabetic retinopathy

\begin{tabular}{|c|c|c|c|}
\hline Characteristics & $\begin{array}{l}\text { Subjects } \\
\text { with PDR }\end{array}$ & $\begin{array}{l}\text { Subjects } \\
\text { without PDR }\end{array}$ & $P$ value \\
\hline Number & 90 & 133 & \\
\hline Age (years) & $64.1 \pm 9.1$ & $69.1 \pm 9.2$ & $<0.001$ \\
\hline Male (\%) & $45(50)$ & $60(45)$ & n. s. \\
\hline $\begin{array}{l}\text { Duration of diabetes } \\
\text { (years) }\end{array}$ & $18.8 \pm 8.8$ & 17.8 & n. s. \\
\hline Insulin therapy & $64(71.1)$ & $64(48.1)$ & $<0.001$ \\
\hline Age at onset of diabetes & $45.2 \pm 10.9$ & $51.5 \pm 10.3$ & $<0.001$ \\
\hline $\mathrm{HbA}_{1 \mathrm{c}}(\%)$ & $8.2 \pm 1.8$ & $8.3 \pm 1.7$ & n. s. \\
\hline $\begin{array}{l}\text { Systolic blood pressure } \\
(\mathrm{mmHg})\end{array}$ & $147 \pm 26$ & $146 \pm 21$ & n. s. \\
\hline $\begin{array}{l}\text { Diastolic blood pressure } \\
(\mathrm{mmHg})\end{array}$ & $88 \pm 11$ & $85 \pm 8$ & 0.02 \\
\hline BMI $\left(\mathrm{kg} / \mathrm{m}^{2}\right)$ & $28.0 \pm 4.4$ & $27.9 \pm 4.6$ & n. s. \\
\hline $\begin{array}{l}\text { History of hypertension } \\
(\%)\end{array}$ & $65(70.4)$ & 95 (71.4) & n. s. \\
\hline Smokers (\%) & $13(14$ & $20(15$ & n. s. \\
\hline Total cholesterol (mmol/l) & $5.3 \pm 1.3$ & $5.4 \pm 1.2$ & n. s. \\
\hline HDL cholesterol (mmol/l) & $1.2 \pm 0.4$ & $1.2 \pm 0.3$ & n. s. \\
\hline LDL cholesterol (mmol/l) & $3.2 \pm 1.10$ & $3.1 \pm 0.9$ & n. s. \\
\hline Triglycerides (mmol/l) & $2.4 \pm 1.6$ & $2.5 \pm 1.9$ & n. s. \\
\hline
\end{tabular}

Table 2 Genotype distributions of C282Y and H63D mutations in patients with and without proliferative diabetic retinopathy (PDR)

\begin{tabular}{lllll}
\hline Mutation/genotype & $\begin{array}{l}\text { Subjects } \\
\text { with }\end{array}$ & $\begin{array}{l}\text { Subjects } \\
\text { without } \\
\text { PDR }\end{array}$ & $\begin{array}{l}\text { OR } \\
(95 \% \mathrm{CI})\end{array}$ & $P$ value \\
& & & \\
\hline
\end{tabular}

\section{C282Y}

YY homozygote

CY heterozygote

CC homozygote

$0(0) \quad 0(0)$

$13(14.4) \quad 7(5.3) \quad 3.0(1.2-8.0)^{1} \quad 0.02^{2}$

H63D

DD

$77(85.6) \quad 126(94.7)$

HD

$\begin{array}{llll}1(1.1) & 3(2.3) & 1.1(0.6-2.2)^{3} & 0.7^{4}\end{array}$

$\mathrm{HH}$

$20(22.2) \quad 25(18.8)$

69 (76.7) 105 (78.9)

${ }^{1}$ Odds ratio $(95 \%$ confidence interval) for dominant model (YY plus CY versus CC)

${ }^{2} P$ value for dominant model (YY plus CY versus CC)

${ }^{3} P$ value for dominant model (DD plus HD versus $\mathrm{HH}$ )

${ }^{4}$ Odds ratio $(95 \%$ confidence interval) for dominant model (DD plus $\mathrm{HD}$ versus $\mathrm{HH}$ )

hemochromatosis $\mathrm{C} 282 \mathrm{Y}$ and $\mathrm{H} 63 \mathrm{D}$ mutations are shown in Table 2. Genotype distribution of the hemochromatosis C282Y and H63D mutations in subjects with and without PDR were compatible with HardyWeinberg expectations (C282Y: PDR $x^{2}=0.545$, $p=0.46$; without PDR $x^{2}=30.097, p=0.755$; H63D: PDR $x^{2}=0.115, p=0.735$; without PDR $x^{2}=1.01$, $p=0.31)$.

There was a significantly higher frequency of the C282Y mutation in subjects with compared to without $\mathrm{PDR}(\mathrm{OR}=3.0,95 \% \mathrm{CI}=1.2-8.0 ; p=0.02)$. There was no $\mathrm{C} 282 \mathrm{Y}$ homozygote among 223 type 2 diabetic patients. In contrast, the H63D genotype was not significantly associated with PDR $(p=0.7)$. Additionally, there was one $(1.1 \%)$ compound heterozygote of $\mathrm{C} 282 \mathrm{Y}$ and H63D in patients with PDR and one $(0.8 \%)$ compound 
Table 3 Logistic regression analysis for the association with retinopathy among type 2 diabetes patients

\begin{tabular}{lll}
\hline Risk factor & OR $(95 \% \mathrm{CI})$ & $P$ value \\
\hline C282Y & $6.1(1.2-30.5)$ & 0.027 \\
Age & $1.05(0.99-1.11)$ & 0.064 \\
Insulin therapy & $2.8(1.3-6.1)$ & 0.01 \\
Age at onset of diabetes & $1.03(0.98-1.08)$ & 0.21 \\
HbA $_{1 c}(\%)$ & $1.2(0.94-1.48)$ & 0.16 \\
Systolic blood pressure & $1.01(0.99-1.03)$ & 0.18 \\
Diastolic blood pressure & $0.91(0.85-0.96)$ & 0.001 \\
\hline
\end{tabular}

heterozygote of $\mathrm{C} 282 \mathrm{Y}$ and $\mathrm{H} 63 \mathrm{D}$ in subjects without PDR (OR 0.8, 95\% CI 0.04-11.1; $p=0.8$ ).

Logistic regression analysis (Table 3 ) showed that in addition to diastolic blood pressure and therapy with insulin, heterozygotes for $\mathrm{C} 282 \mathrm{Y}$ mutation had a significantly increased risk of PDR $(\mathrm{OR}=6.1,95 \%$ $\mathrm{CI}=1.2-30.5 ; p=0.027$ ), suggesting that the $\mathrm{C} 282 \mathrm{Y}$ mutation in the HFE gene is an independent risk factor for PDR.

\section{Discussion}

Carriers of heterozygous hemochromatosis are usually asymptomatic, although the levels of transferrin saturation, serum iron, and serum ferritin differ significantly from those in healthy subjects (Bulaj et al. 1996). Heterozygosity for the $\mathrm{C} 382 \mathrm{Y}$ mutation was associated with a fourfold risk of iron overload (Hanson et al. 2001). Heterozygosity for hemochromatosis-causing mutation $\mathrm{C} 282 \mathrm{Y}$ may therefore be a common genetic marker of lifelong moderate iron overload, whereas serum iron and ferritin concentrations are influenced by short-term effects, such as inflammation, iron intake, alcohol intake, blood loss, diurnal variation, and other illnesses (infections, neoplasia) (Baynes 1996, Bulaj et al. 1996, Cook et al. 1976). Several studies investigating the association of $\mathrm{C} 282 \mathrm{Y}$ heterozygosity with morbidity have given conflicting results, as is exemplified by diabetes, cardiovascular diseases, extrahepatic cancers, and alcoholic liver disease (Fuchs et al. 2002). On the other hand, such association seems unambiguous in the case of sporadic porphyria cutanea tarda (O'Reilly et al. 1997).

It has been recently reported that in the liver and heart increased iron concentrations could increase collagen synthesis and thus fibrosis as well as matrix metalloprotease-2 activity involved in extracellular matrix remodeling (Gardi et al. 2002, Parkes et al. 2000). Moreover, it has been suggested that iron may give a survival advantage to endothelial cells by increasing Bcl-2 expression (Simonart et al. 2001). Both active angiogenesis and the formation of fibrovascular tissue at the vitreoretinal interface are key processes in the pathogenesis of PDR.

Whereas this is the first report of a possible association between the hemochromatosis mutation and complications of diabetic retinopathy, such an associa- tion has been reported previously in the case of another microvascular complication of diabetes - diabetic nephropathy. In 1994, it was reported (Nankivell et al. 1994) that iron overload might cause diabetic nephropathy through accumulation in tubular lysosomes. Moreover, Moczulski et al. (2001) have recently reported that hemochromatosis-causing mutation H63D, but not $\mathrm{C} 282 \mathrm{Y}$, predisposes to diabetic nephropathy. It has been demonstrated that the $\mathrm{C} 282$ mutation alters the HFE protein structure and beta ${ }_{2}$-microglobulin association or cell-surface expression, whereas the H63D mutation, in contrast, does not appear to prevent beta $2_{2}$ microglobulin association or cell-surface expression, indicating that the $\mathrm{C} 282$ mutation results in a greater loss of protein function than does H63D (Feder et al. 1997, Lebron et al. 1998).

Moreover, our study demonstrates that insulin therapy, independently of the C282Y mutation, was statistically significantly associated with PDR. This finding suggests the existence of other factors, such as differences in the ability of insulin secretion, differences in the frequency of episodes of hypoglycemia, or adverse events associated with insulin therapy (hypoglycemia, worsening diabetic retinopathy if $\mathrm{HbA}_{1 \mathrm{c}}$ decreases rapidly) (DeWitt and Hirsch 2003, Dahl-Jorgensen et al. 1985).

It should also be acknowledged that a case-control study design might be subject to error because of unrecognized population stratification, therefore a positive association may be present even when genetic linkage is lacking. Positive results of our association study (the C282 mutation with PDR) may be spurious due to type I error (false positive association study).

In conclusion we suggest that the $\mathrm{C} 282 \mathrm{Y}$ mutation might be a novel risk factor for PDR in patients with type 2 diabetes.

Acknowledgements The authors thank Ms. Mojca Pirc for revising the English.

\section{References}

Baynes RD (1996) Assessment of iron status. Clin Biochem 29: 209-215

Bulaj ZJ, Griffen LM, Jorde LB, Edwards CQ, Kushner JP (1996) Clinical and biochemical abnormalities in people heterozygous for hemochromatosis. N Engl J Med 335:1799-1805

Cook JD, Finch CA, Smith NJ (1976) Evaluation of the iron status of a population. Blood 48:449-455

Dahl-Jorgensen K, Brinchmann-Hansen O, Hanssen KF, Sandvik L, Aagenaes O (1985) Rapid tightening of blood glucose control leads to transient deterioration of retinopathy in insulin dependent diabetes mellitus: the Oslo study. Br Med J (Clin Res Ed) 290:811-815

DeWitt DE, Hirsch IB (2003) Outpatient insulin therapy in type 1 and type 2 diabetes mellitus: scientific review. JAMA 289:2254 2264

Feder JN, Gnirke A, Thomas W, Tsuchihashi Z, Ruddy DA, Basava A, Dormishian F, Domingo R Jr, Ellis MC, Fullan A, Hinton LM, Jones NL, Kimmel BE, Kronmal GS, Lauer P, Lee VK, Loeb DB, Mapa FA, McClelland E, Meyer NC, Mintier 
GA, Moeller N, Moore T, Morikang E, Wolff RK (1996) A novel MHC class I-like gene is mutated in patients with hereditary haemochromatosis. Nat Genet 13:399-408

Feder JN, Tsuchihashi Z, Irrinki A, Lee VK, Mapa FA, Morikang E, Prass CE, Starnes SM, Wolff RK, Parkkila S, Sly WS, Schatzman RC. (1997) The hemochromatosis founder mutation in HLA-H disrupts beta2-microglobulin interaction and cell surface expression. J Biol Chem 272:14025-14028

Fernandez-Real JM, Lopez-Bermejo A, Ricart W (2002) Cross-talk between iron metabolism and diabetes. Diabetes 51:2348-2354

Fuchs J, Podda M, Packer L, Kaufmann R (2002) Morbidity risk in HFE associated hereditary hemochromatosis $\mathrm{C} 282 \mathrm{Y}$ heterozygotes. Toxicology 180:169-181

Gardi C, Arezzini B, Fortino V, Comporti M (2002) Effect of iron on collagen synthesis, cell proliferation and MMP-2 expression in rat hepatic stellate cells. Biochem Pharmacol 64:1139-1145

Hanson EH, Imperatore G, Burke W (2001) HFE gene and hereditary hemochromatosis: a HuGE review. Human genome epidemiology. Am J Epidemiol 154:193-206

Keen H, Lee ET, Russell D, Miki E, Bennett PH, Lu M and the WHO Multinational Group (2001) The appearance of retinopathy and progression to proliferative retinopathy: the WHO multinational study of vascular disease in diabetes. Diabetologia 44 [Suppl 2]:22-30

Klein R, Klein BE, Moss SE, Davies MD, De Mets DL (1984) The Wisconsin epidemiologic study of diabetic retinopathy. III. Prevalence and risk of diabetic retinopathy when age at diagnosis is 30 or more years. Arch Ophthalmol 102:527-532

Lebron JA, Bennett MJ, Vaughn DE, Chirino AJ, Snow PM, Mintier GA, Feder JN, Bjorkman PJ (1998) Crystal structure of the hemochromatosis protein HFE and characterization of its interaction with transferrin receptor. Cell 93:111-123

Moczulski DK, Grzeszczak W, Gawlik B (2001) Role of hemochromatosis $\mathrm{C} 282 \mathrm{Y}$ and $\mathrm{H} 63 \mathrm{D}$ mutations in HFE gene in development of type 2 diabetes and diabetic nephropathy. Diabetes Care 24:1187-1191

Nankivell BJ, Tay YC, Boadle RA, Harris DC (1994) Lysosomal iron accumulation in diabetic nephropathy. Ren Fail16:367-381

O'Reilly FM, Darby C, Fogarty J, Tormey W, Way EW, Leader M, Murphy GM (1997) Screening of patients with iron overload to identify hemochromatosis and porphyria cutanea tarda. Arch Dermatol 133:1098-1101

Parkes JG, Liu Y, Sirna JB, Templeton DM (2000) Changes in gene expression with iron loading and chelation in cardiac myocytes and non-myocytic fibroblasts. J Mol Cell Cardiol 32:233-246

Parkkila S, Waheed A, Britton RS, Feder JN, Tsuchihashi Z, Schatzman RC, et al (1997) Immunohistochemistry of HLA-H, the protein defective in patients with hereditary hemochromatosis, reveals unique pattern of expression in gastrointestinal tract. Proc Natl Acad Sci USA 94:2534-2539

Porta M, Sjoelie AK, Chatuverdi N, Stevens L, Rottiers R, Veglio M, Fuller JH and the EURODIAB Prospective Complications Study Group (2001) Risk factors for progression to proliferative diabetic retinopathy in the EURODIAB Prospective Complications Study. Diabetologia 44:2203-2209

Simonart T, Drgraef C, Stordeur P, Noel JC, Mosselmans R, Van Vooren JP, Parent D, Boelaert JR, Heenen M, Galand P (2001) Iron induces Bcl-2 expression in human dermal microvascular endothelial cells. Free Radic Res 34:221-235

Walsh CH, Malins JM (1978) Proliferative retinopathy in a patient with diabetes mellitus and idiopathic haemochromatosis. Br Med J 2:16-17

World Health Organization diabetes mellitus: report of a WHO study group (1985) WHO Tech Rep Ser No. 727, pp 9-10 